\title{
India: A Brave and Imaginative Superpower?
}

\begin{abstract}
If India can be as successful domestically as Indians are internationally, it can fulfill its potential to become a leading global superpower.
\end{abstract}

Fortune favors the brave, the Ancient Romans said.

This is equally true for individuals as it is for nations. India is now about to enter a geopolitical sweet spot. It will have a once in a millennium opportunity to emerge as the world's most respected superpower. The only question is whether it will be able to muster the courage and the imagination needed to seize this opportunity.

So where does this opportunity come from? It comes from many sources. First, we are entering a new historical era. The artificial era of Western domination of world history is coming to an end. Second, we are seeing the natural return of China and India as the world's largest economies. This is perfectly natural as China and India were the largest economies of the world from 1 to $1820 \mathrm{AD}$, as documented by Angus Maddison. Third, the world has shrunk. As Kofi Annan said, we live in a global village. In the twentieth century, the American century, the United States (US) naturally provided leadership of this global village. Post-Donald Trump, the US has lost its shine. The world is therefore looking for a new guiding light. India can provide a festival of lights.

However, to emerge and be globally acknowledged as a leading superpower, India has to develop a unique combination of three strengths: economic heft, geopolitical shrewdness, and moral courage. All three are within reach of India.

Take economic heft. In theory, India should have the most competitive economy in the world. Empirical evidence backs this claim. The most competitive human laboratory in the world is the US. The best minds from all over the world come to compete in the world's best universities and companies in the US. Guess which ethnic group has the highest per capita income in the most competitive human laboratory? It is the Indian community. Indeed, it is even more striking that if we add up the market capitalization of the American companies that have been run by Indians born in India, including Google, Adobe, Microsoft, MasterCard, PepsiCo, Micron, this sum

Originally published in India On Our Minds, November 2020 
could add up to around USD 2 trillion. By comparison, the gross domestic product of India, with a population of 1.3 billion, is USD 2.7 trillion.

Curiously, even though overseas Indians thrive in competition, India, as a country, is still wary of economic competition. This explains, in part, India's reluctance to join free trade agreements, like the Regional Comprehensive Economic Partnership. The reluctance could have also been due to opposition from vested interests. The corollary of the concept of economic competition is creative destruction. The sad reality is that if India tries to protect its current industries (some of which are globally uncompetitive), it is preventing the emergence of dynamic new industries which could be as globally competitive as the American companies run by Indians. Surely, if Indians can run the most competitive companies in the world, they can also develop the most competitive companies in India. This is why India needs to make a courageous leap into the future with its economic policies. If any Indian government official opens up and liberalizes the Indian economy, it will be rewarded by years of rapid growth a decade later, as proven by the bold liberalization moves made by Manmohan Singh and Montek Singh Ahluwalia in the early 1990s. Jeffrey Sachs of Columbia University and a leading expert on the fight against poverty, states this in his book, The End of Poverty: Economic Possibilities of Our Time. Before the reforms, "India remained trapped with low and erratic growth...Enter Manmohan Singh, who understood clearly that it was time to end the License Raj. From mid-1991 onwards, India became part of the global wave of market reforms..." These reforms were met with a lot of skepticism. Sachs writes: "My protestations that trade liberalization works - that India's exports were bound to grow-were met with repeated warnings that 'India was different'... To nearly worldwide astonishment, India became the hub of large-scale service-sector exports in the new information technologies." Just as courage paid off in the 1990s, it can also pay off in the 2020s.

Similarly, geopolitical shrewdness is clearly within reach of India. There is now no question that the biggest geopolitical contest in the next few decades will be between China and the US, as I document in great detail in my book, Has China Won?, the luckiest country in this geopolitical contest is India. Both the US and China are courting India assiduously as they know that the only country that has the heft to tilt the geopolitical balance one way or another is India. It doesn't take a geopolitical genius to figure out the best place for India to be in this geopolitical context. If an Indian Henry Kissinger or George Kennan were advising India, he would say: just imagine China and the US as two elephants balancing each other on the two ends of a see-saw. The best place for the third elephant to take would be to stand in the middle of the see-saw. Whichever way the third elephant leans will significantly affect the geopolitical balance between the US and China.

This is geopolitical common sense. Yet, it is equally true that a strong head of steam has built up in the Indian body politic against China. Some of it is understandable. China's support of Pakistan against Indian interests has jeopardized Indian security. Yet, this is also where geopolitical shrewdness comes in. During the Cold War, the US supported Taiwan strongly. China claimed Taiwan. The Chinese and American positions were irreconcilable. Mao Zedong and Zhou Enlai could have insisted that Nixon and Kissinger abandon Taiwan completely before China could cooperate with 
the US. China pragmatically ignored the Taiwan issue and instead used the US to increase its geopolitical leverage. China's rapid emergence as an economic power could not have happened if it had not cleverly taken advantage of all the opportunities provided by the US (big markets, access to science and technology, and university education for China's youth). Clearly, China took advantage of its potential future adversary, the US, to enhance the social and economic transformation of its society. Today, India could take advantage of the economic opportunities provided by China, such as, for example, the Belt and Road Initiative (BRI). Right now, joining the BRI is an unthinkable option in India. Geopolitical shrewdness would recommend that no option be deemed unthinkable.

Finally, moral courage. The country that has produced the most morally courageous leader in the world is India. Mahatma Gandhi epitomizes this moral courage. He didn't just care for India. He cared for humanity as a whole. As Prime Minister Narendra Modi said, "Whether it's climate change or terrorism, corruption or selfishness in public life, Gandhiji's ideals are the guiding light for us when it comes to protecting humanity. I believe that the path shown by Gandhiji will lead to a better world."

What would Gandhi say if he were alive today? He was a great admirer of the US. In 1931, he said, "When real Peace and Disarmament come, they will be initiated by a strong nation like America..." Gandhi would therefore be deeply troubled by the rallying cry of President Trump: "Make America Great Again". He would expect America, the richest and most powerful country in the world, to make the world great again.

Yet, it is equally true that there is a great sense of exhaustion in the American body politic about providing leadership to the world. Domestically, America is a deeply troubled society. It is the only major developed society where the average income of the bottom 50 percent has gone down over a 30-year period. As Anne Case and Angus Deaton, two Princeton University economists, say, the white working classes of America used to carry the American dream of getting a better life in their hearts and souls. Today, however, there is a "sea of despair" among them. In view of this, the US can no longer be the "Shining City on the Hill". Neither can China take this role. The Chinese believe that their civilization is one of the best in the world. However, it is a civilization that can primarily be enjoyed by the Chinese. The Chinese, unlike the Americans, have no universalizing mission.

This provides India with a unique opportunity. As we move away from a monocivilizational world dominated by the West to a multicivilizational world where Asian civilizations are coming back strongly, the world is looking for leaders to provide bridges between the East and the West. India is in a unique position to provide such bridges. It is trusted by both the East and the West.

The world is therefore longing for a moral leader like Gandhi who will point out the follies of the many wars that the West had engaged in. Indian voices do speak out. For example, Shyam Saran, a leading Indian official, has written eloquently about the folly of Western interventions.

In most cases, the post-intervention situation has been rendered much worse, the violence more lethal, and the suffering of the people who were supposed to be 
protected much more severe than before. Iraq is an earlier instance; Libya and Syria are the more recent ones. A similar story is playing itself out in Ukraine. In each case, no careful thought was given to the possible consequences of the intervention.

Likewise Shivshankar Menon, former National Security Adviser to the Indian government stated, "Unilateral (sometimes covert) interventions, as in Libya or Syria, have led to unexpected and dangerous outcomes... We clearly need to improve, strengthen and use the processes and institutions of multilateral consultation and action available to the international community." Menon is right. Multilateralism is the solution. India is a natural leader in the multilateral arena.

In 1941, Henry Luce exhorted Americans to realize an American century through an imaginative vision:

No narrow definition can be given to the American internationalism of the 20th Century. It will take shape, as all civilizations take shape, by the living of it, by work and effort, by trial and error, by enterprise and adventure and experience.

And by imagination!

Luce was right. The American century was brilliant and inspiring because it was driven by imagination. Today, India has that opportunity to be equally imaginative. It should seize the moment.

Open Access This chapter is licensed under the terms of the Creative Commons AttributionNonCommercial-NoDerivatives 4.0 International License (http://creativecommons.org/licenses/bync-nd/4.0/), which permits any noncommercial use, sharing, distribution and reproduction in any medium or format, as long as you give appropriate credit to the original author(s) and the source, provide a link to the Creative Commons license and indicate if you modified the licensed material. You do not have permission under this license to share adapted material derived from this chapter or parts of it.

The images or other third party material in this chapter are included in the chapter's Creative Commons license, unless indicated otherwise in a credit line to the material. If material is not included in the chapter's Creative Commons license and your intended use is not permitted by statutory regulation or exceeds the permitted use, you will need to obtain permission directly from the copyright holder.

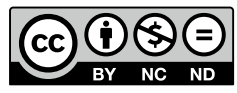

